\title{
PROKRASTINASI AKADEMIK MAHASISWA BIMBINGAN DAN KONSELING UNIVERSITAS PGRI PALEMBANG DALAM MENGERJAKAN SKRIPSI
}

\author{
Erfan Ramadhani \\ Universitas PGRI Palembang \\ Email: erfankonselor@gmail.com
}

\begin{abstract}
ABSTRAK
Skripsi yang menjadi salah satu syarat dalam menyelesaikan studi seringkali menjadi fase yang dinilai berat bagi mahasiswa. Pada penyelesaian skripsi biasanya mahasiswa mendapatkan berbagai rintangan terutama godaan, serta rasa malas yang begitu besar sehingga dalam penyelesaiannya mahasiswa melakukan penundaan dalam penyusunan skripsi. Menunda dalam mengerjakan skripsi dapat dikatakan sebagai prokrastinasi akademik. Penelitian ini merupakan jenis penelitian deskriptif kuantitatif yang nantinya analisis data mengunakan rumus persentase. Subjek penelitian ini adalah 24 orang mahasiswa yang berada di semester sepuluh. Temuan penelitian ini secara umum adalah tingkat prokrastinasi akademik mahasiswa dalam mengerjakan skripsi berada pada kategori sangat tinggi, dengan rata-rata 122,6. Berdasarkan hal tersebut diharapkan permasalahan prokrastinasi akademik tersebut dapat secepatnya diberikan solusi.
\end{abstract}

Kata Kunci: Prokrastinasi Akademik, Mahasiswa Bimbingan dan Konseling

\section{ACADEMIC PROCRASTINATION STUDIES GUIDANCE AND COUNSELING THE UNIVERSITY OF PGRI PALEMBANG IN A THESIS COURSE}

\begin{abstract}
Thesis which is one of the requirements in the studio that is completed becomes the agreed phase for students. At the completion of the thesis, students get various difficulties, temptations, and a sense of laziness that is so great that they can overcome the difficulties of students in completing the thesis. Scripts can help academic procrastination. This research is a quantitative descriptive research that analyzes data using a percentage formula. The subjects of this study were 24 students who were in the tenth semester. The results of this study in general are the level of student academic procrastination in working on the thesis in the very high category, with an average of 122.6. Based on this, it is expected that this solution to academic procrastination can be protected by a solution.
\end{abstract}

Keywords: Academic Procrastination, Studies Guidance and Counseling 


\section{PENDAHULUAN}

Skripsi yang menjadi salah satu syarat dalam menyelesaikan studi seringkali menjadi fase yang dinilai berat bagi mahasiswa. Pada penyelesaian skripsi biasanya mahasiswa mendapatkan berbagai rintangan terutama godaan, serta rasa malas yang begitu besar sehingga dalam penyelesaiannya mahasiswa melakukan penundaan dalam penyusunan skripsi. Menunda dalam mengerjakan skripsi dapat dikatakan sebagai prokrastinasi akademik, yaitu jenis penundaan yang dilakukan pada jenis tugas formal yang berhubungan dengan akademik (Ferrari, Joseph 1995). Mahasiswa yang melakukan penundaan dengan rasa malasnya perlu diberikannya suatu motivasi atau pemahaman sehingga dia mampu serta dapat menyelesaikan skripsinya.

Permasalahan prokrastinasi akademik terutama dalam penundaan dalam mengerjakan skripsi murpakan masalah setiap perguruan tinggi, tidak sedikit perguruan tinggi yang memberikan drop out (DO) kepada mahasiswa yang telah melampaui batas pendidikan yang telah ditentukan. Permasalahan prokrastinasi bukan saja dapat membuat mahasiswa di DO akantetapi dapat juga berdanpak negatif pada mahasiswa itu sendiri diantaranya, mahasiswa tidak dapat menyelesaikan studinya, mahasiswa mengalami kerugian berkaitan dengan usia semakin menua, biaya kuliah selalu terus dikeluarkan dan bahkan dapat membuat mahasiswa stress dan bahkan berujung keinginan untuk mengakhiri hidupnya.

Masalah ini terjadi di Universitas Padjajaran, terdapat mahasiswa tewas gantung diri di kosannya. Berdasarkan keterangan Kapolres Sumedang AKBP Hartoyo mahasiswa ini meninggal diakibatkan bunuh diri karena permasalahan skripsi dan masalah keuangan keluarga (Putra, Wisma. 2018). Selanjutnya, berita berita di Bengkulu today.com 2018 memberitakan tentang enam mahasiswa nekat bunuh diri dikarenakan skripsi tak kelar-kelar. Berita ini membeberkan bahwa enam mahasiswa ini berada di berbagai universitas diantaranya, mahasiswa universitas sriwijaya palembang, universitas Kapuas Kalimantan timur, mahasiswa di Jakarta Selatan, mahasiswa universitas Sumatera Utara, mahasiswa STIKES Kandal, dan mahasiswa Universita Veteran Bangun Nusantara Jawa Tengah. Berdasarkan berita 
tersebut dapat disimpulkan bahwa rata-rata mahasiswa yang melakukan bunuh diri merupakan mahasisiswa tingkat akhir dan sendang dalam penyelesaian skripsi.

Berdasarkan permasalahan tersebut di atas, dapat dipahami bahwa penundaan dalam mengerjakan skripsi akan memberikan danpak buruk bagi mahasiswa. Penundaan ini pula terjadi di Program Studi Bimbingan dan Koseling Fakultas Keguruan dan Ilmu Pendidikan Universitas PGRI Palembang. Pada Program Studi Bimbingan dan Konseling masih terdapat 24 orang mahasiswa yang saat ini sedang berada pada semester sepuluh. Berdasarkan hal ini maka peneliti tertarik untuk melakukan suatu kajian mengenai gambaran prokrastinasi akademik mahasiswa Bimbingan dan Konseling dalam mengerjakan skripsi.

\section{METODOLOGI PENELITIAN}

Desain penelitian yang digunakan dalam penelitian ini adalah penelitian deskriptif kuantitatif. Menurut Irawan (1996:60) penelitian deskriptif adalah penelitian yang bertujuan mendeskriptifkan atau menjelaskan suatu hal sebagaimana adanya secara aktual. Jenis penelitian yang akan digunakan adalah penelitian deskriptif komparatif. Subana (2001:89) mengemukakan bahwa penelitian dengan format deskriptif adalah penelitian yang bertujuan untuk menjelaskan, meringkaskan kondisi dengan berbagai situasi, atau berbagai variabel yang timbul dimasyarakat berdasarkan apa adanya sesuai dengan kenyataan. Instrumen dalam penelitian ini mengunakan skala model likert dengan rentang skala lima.

Berkaitan dengan ini Yusuf (2005:82) bahwa penelitian deskriptif adalah salah satu jenis penelitian yang bertujuan untuk mendeskripsikan secara sistematis, faktual dan akurat mengenai fakta-fakta dan sifat populasi tertentu dan mencoba menggambarkan fenomena secara mendetail apa adanya, artinya penelitian deskriptif adalah penelitian yang menggambarkan sesuatu yang sedang terjadi apa adanya. Hasil penelitian ini akan dideskripsikan mengunakan rumus persentase. Menurut Sudjana (2002:50) persentase dapat dihitung dengan menggunakan rumus sebagai berikut: 


$$
P=\frac{f}{N} \times 100
$$

$\begin{array}{lll}\text { Keterangan: } & \text { P } & \text { : Persentase } \\ & \text { f } & \text { : Frekuensi Jawaban } \\ & \text { N } & \text { : Jumlah Responden }\end{array}$

Pembuatan kriteria penilaian menggunakan mean hypothetic. Adapun formula yang digunakan sebagai berikut:

$$
\begin{aligned}
& \mathrm{I} \quad=(\mathrm{ST}-\mathrm{SR}): 5 \\
& \mathrm{ST}=\geq \mathrm{ST}-\mathrm{I} \\
& \mathrm{T}=\mathrm{ST}-2 \mathrm{I}<\mathrm{ST}-\mathrm{I} \\
& \mathrm{S}=\mathrm{ST}-3 \mathrm{I}<\mathrm{ST}-2 \mathrm{I}
\end{aligned}
$$

(Irianto, 2010:22)

Keterangan:

$$
\begin{aligned}
& \mathrm{I}=\text { Interval } \quad \mathrm{ST}=\text { Sangat Tinggi } \quad \mathrm{R}=\text { Rendah } \\
& \text { ST = Skor Tertinggi } \quad \mathrm{T}=\text { Tinggi } \quad \mathrm{SR}=\text { Sangat Rendah } \\
& \mathrm{SR}=\text { Skor Terendah } \quad \mathrm{S}=\text { Sedang }
\end{aligned}
$$

\section{HASIL PENELITIAN DAN PEMBAHASAN}

\section{HASIL PENELITIAN}

Berdasarkan penyebaran instrument prokrastinasi akademik mahasiswa dalam mengerjakan skripsi kepada 24 responden maka diperoleh data berikut.

Tabel 1. Data Tingkat Prokrastinasi Akademik Mahasiswa dalam mengerjakan skripsi

\begin{tabular}{|c|c|c|}
\hline \multicolumn{3}{|c|}{ Data Tingkat Prokrastinasi Akademik } \\
\hline Kode Mahasiswa & Skor & Kategori \\
\hline E 1 & 118 & Sangat Tinggi \\
\hline E 2 & 141 & Sangat Tinggi \\
\hline E 3 & 127 & Sangat Tinggi \\
\hline E 4 & 112 & Tinggi \\
\hline E 5 & 144 & Sangat Tinggi \\
\hline E 6 & 107 & Tinggi \\
\hline E 7 & 114 & Sangat Tinggi \\
\hline E 8 & 117 & Sangat Tinggi \\
\hline E 9 & 141 & Sangat Tinggi \\
\hline E 10 & 114 & Sangat Tinggi \\
\hline E 11 & 110 & Tinggi \\
\hline
\end{tabular}




\begin{tabular}{|c|c|c|}
\hline E 12 & 111 & Tinggi \\
\hline E 13 & 105 & Tinggi \\
\hline E 14 & 133 & Sangat Tinggi \\
\hline E 15 & 111 & Tinggi \\
\hline E 16 & 133 & Sangat Tinggi \\
\hline E 17 & 127 & Sangat Tinggi \\
\hline E 18 & 131 & Sangat Tinggi \\
\hline E 19 & 144 & Sangat Tinggi \\
\hline E 20 & 120 & Sangat Tinggi \\
\hline E 21 & 118 & Sangat Tinggi \\
\hline E 22 & 113 & Sangat Tinggi \\
\hline E 23 & 132 & Sangat Tinggi \\
\hline E 24 & 119 & Sangat Tinggi \\
\hline Rata-Rata & $\mathbf{1 2 2 , 6}$ & Sangat Tinggi \\
\hline
\end{tabular}

Berdasarkan hasil penyebaran instrument tersebut dari 24 orang mahasiswa yang memiliki prokrastinasi akademik dalam mengerjakan skripsi dalam kategori sangat tinggi sebanyak 18 orang, dalam kategori tinggi 6 orang. Berdasarkan data di atas, dapat disimpulkan bahwa prokrastinasi akademik mahasiswa berada dalam kategori sangat tinggi dengan nilai rata-rata sebesar 122,6.

Selanjutnya, berdasarkan hasil penyebaran instrument prokrastinasi akademik mahasiswa dalam mengerjakan skripsi, maka dapat dirumuskan distribusi frekuensi dalam bentuk table berikut.

Tabel 2. Distribusi Frekuensi Prokrastinasi Akademik mahasiswa dalam mengerjakan skripsi.

\begin{tabular}{|c|c|c|c|}
\hline Interval & Kategori & Frekuensi & \% \\
\hline$\geq 134$ & Sangat Tinggi & 18 & 75 \\
\hline $108-133$ & Tinggi & 6 & 25 \\
\hline $82-107$ & Sedang & 0 & 0 \\
\hline $56-81$ & Rendah & 0 & 0 \\
\hline$\leq 30$ & Sangat Rendah & 0 & 0 \\
\hline \multicolumn{2}{|c}{ Jumlah } & 24 & 100 \\
\hline
\end{tabular}

Berdasarkan tabel di atas, diketahui dari 24 orang mahasiswa yang memiliki prokrastinasi akademik berada dalam kategori sangat tinggi sebanyak 18 orang 
dengan persentase $75 \%$, pada kategori tinggi sebanyak 6 orang dengan persentase $25 \%$.

\section{PEMBAHASAN}

Berdasarkan dari penyebaran instrument prokrastinasi akademik mahasiswa dalam mengerjakan skripsi kepada 24 orang responden, maka dapat disimpulkan bahwa tingkat prokrastinasi akademik mahasiswa dalam mengerjakan skripsi berada dalam kategori sangat tinggi. Rata-rata skor prokrastinasi akademik mahasiswa dalam mengerjakan skripsi sebesar 122,6 berdasalkan dari data ini dapat disimpulkan bahwa mahasiswa bimbingan dan konseling mengalami masalah dengan prokrastinasi akademik. Prokrastinasi akademik merupakan suatu tindakan penunda-nundaan dalam mengerjakan sesuatu tugas, baik tugas perkuliahan maupun tugas dalam mengerjakan skripsi. Prokrastinasi juga merupakan perilaku yang negatif dengan beberapa komponen dianaranya; perilaku lalai, keragu-raguan, kurangnya ketepatan waktu, serta kurangnya perencanaan dalam melakukan sesuatu.

Tuckman (1990) menjelaskan "Procrastination is attitudinally and behaviorally" maksudnya, penundaan adalah sikap dan perilaku. Sikap dan perilaku penundaan yang ada pada diri mahasiswa ketika memulai dan mengerjakan tugas, yang terdiri dari tugas individu maupun tugas kelompok yang diberikan oleh dosen, dengan adanya kebiasaan tersebut maka berdanpak pada penunda-nundaan dalam mengerjakan tugas akhir atau skripsi. Selanjutnya, Indra (2015:119) mengungkapkan "Mahasiswa yang cendrung melakukan prokrastinasi akademik adalah mahasiswa yang memiliki pemikiran yang irrasional dalam pengaturan waktu serta cenderung melakukan hal-hal yang tidak bermanfaat daripada untuk belajar atau mengerjakan tugas".

\section{KESIMPULAN}

Berdasarkan uraian di atas, maka secara umum dapat disimpulkan bahwa tingkat prokrastinasi akademik mahasiswa bimbingan dan konseling berada pada kategori sangat tinggi. Tingkat prokrastinasi akademik ini diharapkan dapat 
diselesaikan karena akan berdanpak negatif kepada perkembangan masa depan mahasiswa apabila terus dibiarkan. Adapun solusi yang diharapkan yaitu diberikan perlayanan kusus serta pendalaman permasalahan yang dihadapi mahasiswa. Dengan adanya pendalaman permasalahan tersebut maka dapat diberikan suatu solusi agar permasalahan itu dapat cepat terselesaikan. Salahsatu cara dalam mengatasi permasalahan itu dengan diberikan pelayanan konseling diantaranya pelayanan informasai, bimbingan kelompok serta pelayanan konseling yang menyeluruh sehingga masalah tersebut dapat diatasi.

\section{DAFTAR PUSTAKA}

Bengkulu. Today.com. 2018. Skripsi Tak Kelar-Kelar, 6 Mahasiswa ini Nekad Bunuh Diri. Diakses pada 27 Januari 2019 Tersedia [Online] https://www.bengkulutoday.com/skripsi-tak-kelar-kelar-6-mahasiswa-ininekad-bunuh-diri

Ferrari, Joseph R., Johnson, J. \& McCown, W. 1995. Procrastination and Task Avoidance. New York, USA: Plenum Press.

Indra, S. 2015. Efektivitas Layanan Informasi dengan Menggunakan Teknik Team Assisted Individualization untuk Mengurangi Prokrastinasi Akademik. Tesis tidak diterbitkan. Prodi S2 BK FIP UNP.

Irawan, Prasetya. 1996. Logika dan Prosedur Penelitian. Jakarta: STIA-LAN Press.

Irianto. 2012. Statistik (Konsep Dasar, Aplikasi dan Pengembangannya). Jakarta: Kencana Prenada Media Grob.

Putra, Wisma. 2018. Diduga Stres Skripsi, Mahasiswa Unpad Gantung Diri di Indekos. detikNews. Diakses pada 27 Januari 2019 Tersedia [Online] https://news.detik.com/berita-jawa-barat/d-4357539/diduga-stres-skripsimahasiswa-unpad-gantung-diri-di-indekos.

Subana, M. 2001. Dasar-Dasar Penelitian Ilmiah. Bandung: Pustaka Setia.

Sudjana, N. 2002. Penilaian Hasil Proses Belajar Mengajar. Bandung: Remaja Rosdakarya.

Tuckman. 1990. Measuring Procrastination Attitudinally and Behaviorally. Journal Procrastination Scale. Florida State University.

Yusuf, A. M. 2005. Metodologi Penelitian.. Padang: UNP Press.

Yusuf, A. M. 2013. Metode Penelitian Kuantitatif, Kualitatif, dan Penelitian Gabungan. Padang: UNP Press. 